\title{
Structural characteristics of mangrove forests in Brazilian estuaries: A comparative study
}

\author{
Características estructurales de los manglares en los estuarios de Brasil: \\ Un estudio comparativo
}

\section{Rafaela Camargo Maia ${ }^{1}$ and Ricardo Coutinho ${ }^{2}$}

\author{
${ }^{1}$ Instituto Federal de Educação, Ciência e Tecnologia do Ceará, Campus Acaraú, Avenida Desembargador Armando de Sales \\ Louzada, s/n, CEP 62580-000, Acaraú CE, Brasil. rafaelacmaia@yahoo.com.br \\ ${ }^{2}$ Instituto de Estudos do Mar Almirante Paulo Moreira, Departamento de Oceanografia, Divisão de Bioincrustação, Arraial \\ do Cabo, RJ, CEP: 28930-000, Brasil
}

\begin{abstract}
Resumen.- Se caracterizó la estructura de la vegetación de los bosques de manglares en 9 estuarios en el estado de Ceará, nordeste de Brasil, con el propósito de compararlos y lograr concesión de subvenciones para su conservación. Se utilizó el método de los cuadrados múltiples, con 3 transectos de 5 cuadrantes en cada sitio. Se obtuvieron valores de diámetro y área basal de los árboles, la dominancia, la densidad del tronco y la frecuencia relativa de cada especie, además de las variables para el análisis de los sedimentos. Los resultados de los parámetros estructurales obtenidos mostraron diferencias entre los bosques de la muestra, de forma que los niveles más altos de densidad se hallaron en los ríos Acaraú, Ceará y Guriú. El rio Guriú además presentó los menores valores de altura, área basal y Diámetro a la altura del pecho (DAP). El análisis de agrupamiento de especies indica una separación de 3 grupos: 1) Cocó y Ceará, 2) Acaraú, Jaguaribe y Pacoti, y 3) Aracatimirim y Guriú. Los bosques de manglares en Curú y Barra Grande no conformaron ningún grupo con los anteriores. El Análisis de Componentes Principales (ACP) indicó que los sedimentos recogidos en los estuarios presentan una composición distinta. Las diferencias entre los sitios se deben tener en cuenta cuando se proponga la administración, ya que cada manglar exige estrategias diferentes para su mantenimiento.
\end{abstract}

Palabras clave: Ceará, estructura de la planta, sedimento, vegetación

\begin{abstract}
The aim of this study was the characterization of mangrove forests in 9 estuaries in the state of Ceará, northeastern Brazil, with the purpose of comparing them and providing subsidies for their conservation. We used the method of multiple squares, having 3 transects of 5 quadrats at each site. We obtained values for the diameter and basal area of the individuals, dominance, trunk density and relative frequency per species, as well as variables for the analysis of sediment. The results obtained regarding structural parameters showed differences among the sampled forests, where the highest density levels were found in the Acaraú, Ceará and Guriú rivers. The Guriú River also presented the smallest values for height, Diameter at Breast Height (DBH) and basal area. The grouping analysis indicates 3 groups of forests: 1) Cocó and Ceará; 2) Acaraú, Jaguaribe and Pacoti, and 3) Aracatimirim and Guriú. The mangrove forests in Curú and Barra Grande were not grouped. The Principal Component Analysis (PCA) indicated that the sediments collected in the estuaries present a distinct texture composition. The differences between the areas must be taken into consideration when proposing management, as each mangrove demands different strategies for its maintenance.
\end{abstract}

Key words: Ceará, plant structure, sediment, vegetation

\section{INTRODUCTION}

Mangrove is a coastal ecosystem found in tropical regions around the world, which are characterized by typically ligneous vegetation which is associated with other components of flora and fauna well adapted to limiting conditions of salinity, unconsolidated substrate, little oxygen and a habitat frequently submerged by tides (Schaeffer-Novelli 1995). These ecosystems occupy a significant portion of Brazilian coast, around $90 \%$ of the coastline $(6.786 \mathrm{~km})$ from the northern point in Oiapoque, in the state of Amapá, to the southern limit in Santa Catarina (Schaeffer-Novelli et al. 1990, FAO 2007). The great importance of mangrove is related to the role that this ecosystem plays in the maintenance of fish stock and sea biodiversity as it acts as a shelter for species, as 
well as constituting an important source of organic material for adjoining waters (Spalding et al. 2010). This exported material, enriched with fungi and bacteria, constitutes the basis of the food web in those environments (Lugo \& Snedaker 1974, Robertson \& Daniel 1989, Fleming et al. 1990, Vannucci 2001, Sheridan \& Hays 2003).

The intense use of natural resources threatens the existence of mangrove ecosystems, as many of these coastal areas have become large economic and population centers (Schaeffer-Novelli et al. 2000, FAO 2007, Jablonski \& Filet 2008). The main potential impact-generating vectors include the barring of rivers, extraction of fauna, aquaculture, production of salt and urbanization which results in pressure being put on the balance of sediments and water chemistry in estuaries and the flowing of nutrients and polluting material (Ellison \& Farnsworth 1996, 2001, Fondo \& Martens 1998, Alongi 2002, Spalding et al. 2010). Worth highlighting is the growing pressure made by carciniculture, mainly in the Northeast states of Brazil, with emphasis on Pernambuco, Rio Grande do Norte and Ceará (Schaeffer-Novelli et al. 2000, SEMACE 2006, Nascimento et al. 2007). This activity has a disorganized growth in carciniculture without proper control of environmental changes, provoking serious environmental, social and economical damage on local and regional scales. The effects on the coastal environment present themselves through erosion and sedimentation, eutrophication and changes in the food web and communities' structure (Fondo \& Martens 1998, Ellison \& Farnsworth 1996, 2001, Alongi 2002, Nascimento et al. 2007).

Nowadays, in addition to intense local and regional impacts on mangroves, global climate change is putting pressure on the dynamics of the ecosystems and their communities, with scale and intensity still uncertain (FAO 2007). Changes in temperature, rainfall and elevations in sea level have the potential to change existing hydrological and biogeochemical characteristics, threatening the biodiversity and ecological balance of the mangrove (Gilman et al. 2008, Soares 2009).

The plant structure of mangrove directly influences the conditions and functioning of mangrove forests, and its alteration may influence the distribution and abundance of fauna (Soares 1999, Cavalcanti et al. 2009). Therefore, its characterization constitutes an important tool in understanding how this ecosystem responds to existing environmental conditions, aiding in studies which aim to achieve its preservation. For example, the impacts of extracting or cutting trees to build tanks in which to raise animals, for community and commercial uses, reduces the energy available within the ecosystem, reducing productivity and resulting in a smaller structural vigor of forests, especially when considering the values obtained for average height, diameter, basal area and density of trees (Peria et al. 1990, Souza \& Sampaio 2001, Atheull et al. 2009).

Along of Brazilian coast, mangroves present very different structural characteristics (Peria et al. 1990, Schaeffer-Novelli et al. 1990, Schaeffer-Novelli \& CintrónMolero 1994, Soares 1999, Souza \& Sampaio 2001, Soares et al. 2003, Bernini \& Rezende 2004, Silva et al. 2005, Cunha-Lignon et al. 2009, Menghini et al. 2011). In Ceará state, there is little information on structural and functional attributes, as well as on the dynamics of mangroves, which makes determining the structural pattern of the ecosystem difficult for this state. As this state in the Northeast of Brazil is affected by major anthropogenic impacts, it is important to know the structure and the functional attributes in order to preserve this important ecosystem. Thus, the objective of this study was to characterize the structure of mangrove forests, evaluating height, diameter and basal area of the individuals, dominance, trunk density and relative frequency per species, and sedimentology in nine estuaries in Ceará state, Brazil, covering all the state's coast, with the aim of comparing them and providing subsidies for their preservation.

\section{MATERIAL AND METHODS}

\section{Area OF STUdY}

The state of Ceará has an area of $48,016 \mathrm{~km}^{2}$, with about $570 \mathrm{~km}$ of coastline where $182.25 \mathrm{~km}^{2}$ of that is mangrove area (SEMACE 2006). The weather is mainly semi-arid, with an annual rain average of $800 \mathrm{~mm}$. The coastline is subject to a regime of mid-tides (tidal amplitudes between 2 and $4 \mathrm{~m}$ ), where predominant high energy tides, leads to the formation of sandy beaches and associated dunes. In general, mangrove forests in this region occur as small extensions and are limited to estuarine systems. In these systems, there is less impact from high salt concentration induced by the dry weather, as there is the formation of important hyper-saline hills, where areas sheltered from hydro-dynamism can be found. The entry of freshwater represents small values; the total annual average of river discharge is smaller than $1,000 \mathrm{~m}^{3} \mathrm{~s}^{-1}$, and is highly seasonal. The largest discharge of freshwater into the sea occurs during the rainy season, usually at the end of 
the year, in December, and goes until May, while the opposite occurs during the dry season, from July to November (FUNCEME 2010 ${ }^{1}$ )

This study was carried out within nine estuaries in the state of Ceará, three being in the metropolitan region of Fortaleza, the state capital, (Ceará, Cocó and Pacoti), three in main rivers (Acaraú, Curú and Jaguaribe) and three in rivers which are considered secondary (Aracatimirim, Guriú and Barra Grande) (Fig. 1), from March to June 2007. The selection of areas for the study considered the following criteria: representativeness, importance and accessibility.

\section{Characterization of Mangrove}

The characterization of the plant structures of mangrove was based on the methodology proposed by SchafferNovelli \& Cintrón (1986), which recommends the use of multiple squares, the replication of samples in order to be more representative and to allow for more robust statistical analysis. In each location, three sites were chosen and each area was marked by transects of 5 quadrats measuring $100 \mathrm{~m}^{2}$ each, located $5 \mathrm{~m}$ away from each other. However, in the estuaries of the Guriú and Pacoti rivers, only three quadrats were marked for each transect due to the small extension of the mangrove. The quadrats were oriented perpendicularly to the river and the first was $10 \mathrm{~m}$ away from its bank (Fig. 2). In each quadrat, mangrove trees were identified according to species, had their sizes estimated and their diameter measured from breast height (1.30 $\mathrm{m}$ from the floor) (DBH), with the aid of a measuring tape. In case of forked trunks, we considered them as two separate trunks and registered both measurements. Later, data on width were transformed into $\mathrm{DBH}$ and for each area; we measured the average height, average DBH, individual basal area (dominance), density of living and dead trunks, and the relative frequency by species. We also analyzed the relation between the numbers of trunks per individual (SchaefferNovelli \& Cintrón 1986).

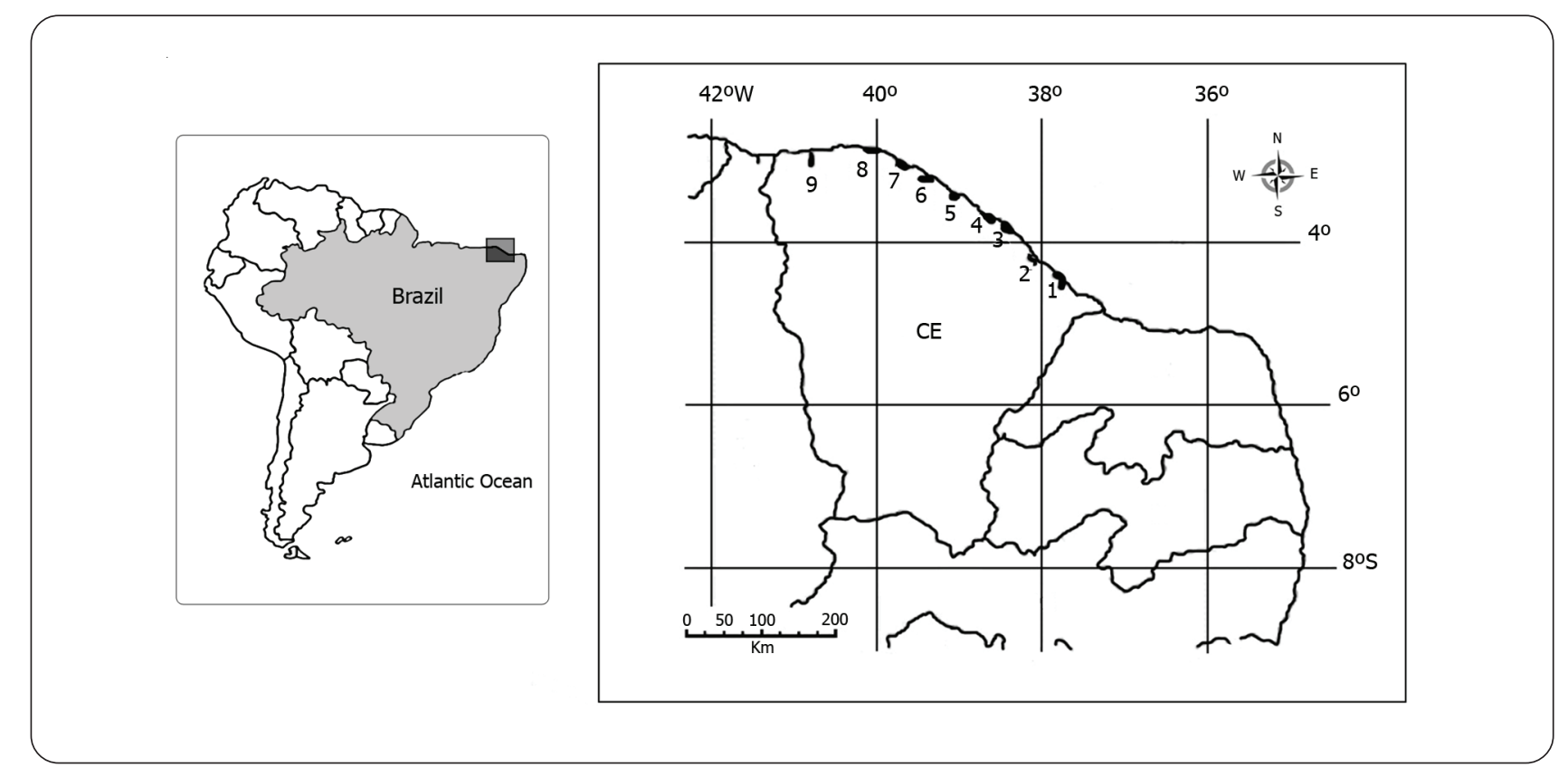

Figure 1. Map of Ceará state (CE) showing the mangrove areas and sampling sites. 1. Barra Grande, 2. Jaguaribe, 3. Cocó, 4. Pacoti, 5. Ceará, 6. Curú, 7. Aracatimirim, 8. Acaraú, 9. Guriú. Dark points indicate the mangrove areas / Mapa del estado de Ceará (CE), que muestra las zonas de manglares con los sitios de muestreo. 1. Barra Grande, 2. Jaguaribe, 3. Coco, 4. Pacoti, 5. Ceará, 6. Curú, 7. Aracatimirim, 8. Acaraú, 9. Guriú. Puntos oscuros indican las zonas de manglares

${ }^{1}$ FUNCEME. 2010. Fundação Cearense de Meteorologia e Recursos Hídricos, Posto de Acaraú. [on line] <http://www. funceme.br> 


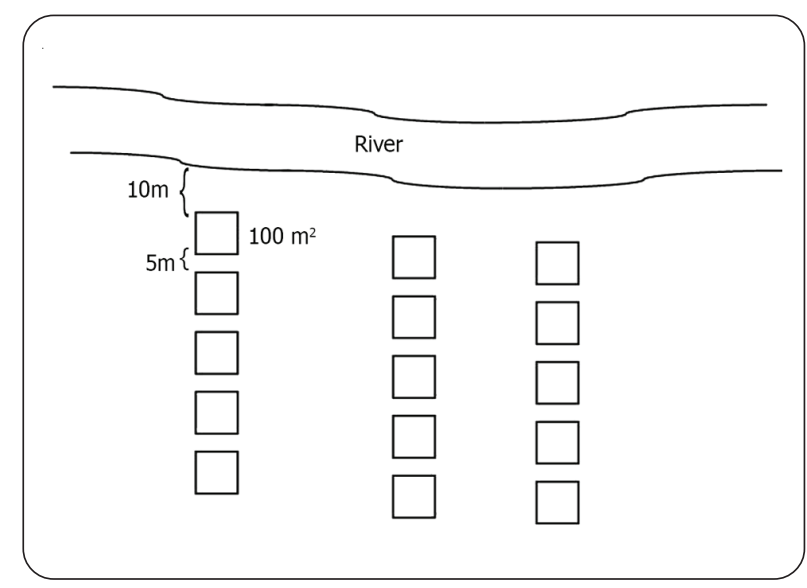

Figure 2. Schematic drawing of the methodology used for structural characterization of mangrove forests in areas of study / Esquema de la metodología utilizada para la caracterización estructural de los manglares en las zonas de estudio

In each area we also obtained values for water salinity in the estuary with the aid of a refractometer. During low tide, 3 samples of superficial sediment $(0-15 \mathrm{~cm})$ were collected, one in each transect. The samples were stored in plastic bags and taken to the Instituto de Ciências do Mar, LABOMAR from Universidade Federal do Ceará UFC where they were frozen for later granulometric analysis procedures and the analysis of organic material content (OMC).

For granulometric analysis, the samples of sediments collected in the field were initially kept at $60^{\circ} \mathrm{C}$ in a heater to dry, then they were quartered and fractioned in $100.0 \mathrm{~g}$ of the sediment sample. Then, the processed material was wet sifted which separated muddy and sandy fractions (limit for classes $=0.062 \mathrm{~mm}$ for diameter size). Then, the sample was mechanically sifted where the classes of sand and rock chips are split. In other words, fractions from $0.062 \mathrm{~mm}$ to $2.00 \mathrm{~mm}$ in diameter for the classes of sand and fractions with diameter higher than $2.00 \mathrm{~mm}$ for the definition of rock chips. The results of the granulometric analyses (phi values for thin and coarse fractions of each sample) were submitted to the granulometric analysis program ANASED 5j, developed in the Laboratório de Geologia Marinha Aplicada from the Universidade Federal do Ceará. To obtain the OMC, we calculated the difference between the known initial mass of the sediment $( \pm 3 \mathrm{~g})$ and its mass after calcinations in a muffle oven at $450^{\circ} \mathrm{C}$ for $2 \mathrm{~h}$. Then we used the following expression: organic material $=($ lost mass $\times 100) /($ sediment mass $)($ Loring \& Rantala 1992).
The structural parameters of the plants (height, DBH, basal area, trunk/individual relation and density) were analyzed by descriptive statistics, later normality and homogeneity of data were tested. In order to compare the structural parameters among the mangrove forests, we used a one way variance analysis (ANOVA). Every statistical analysis used data per quadrat and dead individuals were not considered during the analysis. Once differences at the level of significance of $95 \%(P<0.05)$ between averages were detected, Tukey's test of multiple comparisons was used.

Variation pattern of communities' structure was evaluated as a grouping analysis (Cluster) based on BrayCurtis' similarity index, using PRIMER v6 program (Plymouth Routines In Multivariate Ecological Research, Clarke \& Gorley 2006). These analyses considered values of relative density of species. Also through this program, the Analysis of Similarity (ANOSIM) and Percentage of Similarity (SIMPER) were made, aiming to detect space variations among mangroves. To detect sediment distribution patterns among the mangroves, a Principal Component Analysis (PCA) was applied, using the following parameters: rock chips, sand, clay, silt and organic material percentages. The relation between the multivariate structure of the community and sedimentology variables was analyzed using Correlation Analysis. To subsidize the selection of environmental descriptors used in this analysis, a correlation among all the variables was used, taking out of the analysis highly correlated parameters $(\mathrm{R}>0.95)$. All data used in the statistic analysis were transformed using $\log (\mathrm{x}+1)$.

\section{Results}

Four mangrove species were sampled in the nine estuaries: Avicennia germinans (Linnaeus) Stearn, Avicennia schaueriana Stapft \& Leechman (Avicenniaceae), Rhizophora mangle Linnaeus (Rhizophoraceae) and Laguncularia racemosa (Linnaeus) Gaertn (Combretaceae). R. mangle was the most dominant and frequent species in the studied sites, considering the total basal area of individuals (Table 1). On the other hand, in Ceará and Cocó rivers, A. schaueriana was the predominant species, and in Jaguaribe estuary, $A$. germinans (Table 1). In Acaraú mangroves there was codominance between $R$. mangle (43.7\%) and A. germinans (41\%) (Table 1). 
The density of living individuals was not similar among mangroves, where significant differences were shown among the areas $\left(\mathrm{F}_{(8,126)}=5.516, P<0.001\right)$ (Fig. 3). We can observe the formation of 3 distinct groups of tree densities; the first was made by denser mangroves, Acaraú, Ceará and Guriú, the second composed of Barra Grande, Jaguaribe and Pacoti estuaries' with intermediate values, and the third includes areas with the lowest density (Aracatimirim, Cocó and Curú). Trunk/individual relation was also different among the sampled areas $\left(\mathrm{F}_{(8}\right.$ $\left.{ }_{126)}=10.353, P<0.001\right)$ where Acaraú presented significantly higher values (mean \pm standar deviation, $1.40 \pm 0.76)$ (Table 2).
The total average height of the forests studied was between $6.3 \pm 3.9$ and differed significantly among the mangrove sites $\left(\mathrm{F}_{(8,126)}=8.853, P<0.001\right)$. The estuaries of Ceará and Cocó rivers presented the highest values $(8.77 \pm 5.07 \mathrm{~m})$ (Fig. 4). We observed 3 distinct height patterns, the first was made up of taller mangroves (Ceará and Cocó), another with mangroves of intermediate height (Aracatimirim and Curú) and the third of individuals with lower values for height (Acaraú, Jaguaribe, Guriú, Barra Grande and Pacoti). Besides, noticed was the tendency of decreasing tree height towards the west coast of the state, from the estuary of Ceará River to Guriú (Fig. 4).

Table 1. Relative dominance (Do) and frequency (Freq) of mangrove species in the studied estuaries. Values are percentage / Dominancia relativa (Do) y frecuencia (Freq) de las especies de manglares en los estuarios estudiados. Los valores son porcentajes

\begin{tabular}{lccccccccc}
\hline Parameters/Estuaries & Barra Grande & Jaguaribe & Cocó & Pacoti & Ceará & Curú & Acaraú & Aracatimirim & Guriú \\
\hline Do R. mangle & 92.42 & 35.45 & 22.36 & 52.36 & 13.59 & 94.91 & 43.78 & 49.96 & 61.11 \\
Do A. germinans & 0 & 44 & 6.28 & 9.58 & 1.57 & 2.24 & 41.03 & 34.04 & 34.09 \\
Do $A$. schaueriana & 7.57 & 9.36 & 45.35 & 11.61 & 53.61 & 0.97 & 10.86 & 16 & 4.37 \\
Do L. racemosa & 0.01 & 11.19 & 26.01 & 26.45 & 31.23 & 1.87 & 4.33 & 0 & 0.42 \\
Freq R. mangle & 61.9 & 27.03 & 31.43 & 34.62 & 32.58 & 57.69 & 31.82 & 48 & 37.5 \\
Freq $A$. germinans & 0 & 29.73 & 8.57 & 19.23 & 12.36 & 11.54 & 29.55 & 20 & 37.5 \\
Freq $A$. schaneriana & 33.33 & 18.92 & 34.29 & 26.92 & 37.45 & 11.54 & 22.73 & 32 & 20.83 \\
Freq L. racemosa & 4.76 & 24.32 & 25.71 & 19.23 & 17.6 & 19.23 & 15.91 & 0 & 4.17 \\
\hline
\end{tabular}

Table 2. Total basal area $\left(\mathrm{m}^{2}\right)$ and trunk/individual relationship in the estuaries (mean \pm standard deviation) / Área basal total $\left(\mathrm{m}^{2}\right)$ y la relación tronco/individuo en los estuarios (media \pm desviación estándar)

\begin{tabular}{lcc}
\hline \multicolumn{1}{c}{ Estuaries } & $\begin{array}{c}\text { Trunk / individual } \\
\text { relation }\end{array}$ & $\begin{array}{c}\text { Total } \\
\text { basal area }\left(\mathrm{m}^{2}\right)\end{array}$ \\
\hline Barra Grande & $1.03 \pm 0.16$ & 1.3912 \\
Jaguaribe & $1.05 \pm 0.23$ & 2.1174 \\
Cocó & $1.03 \pm 0.17$ & 1.7531 \\
Pacoti & $1 \pm 0$ & 0.6005 \\
Ceará & $1.13 \pm 0.48$ & 2.9739 \\
Curú & $1.05 \pm 0.24$ & 2.8056 \\
Acaraú & $1.4 \pm 0.76$ & 2.6848 \\
Aracatimirim & $1.11 \pm 0.37$ & 2.3798 \\
Guriú & $1.01 \pm 0.11$ & 0.4717 \\
\hline
\end{tabular}



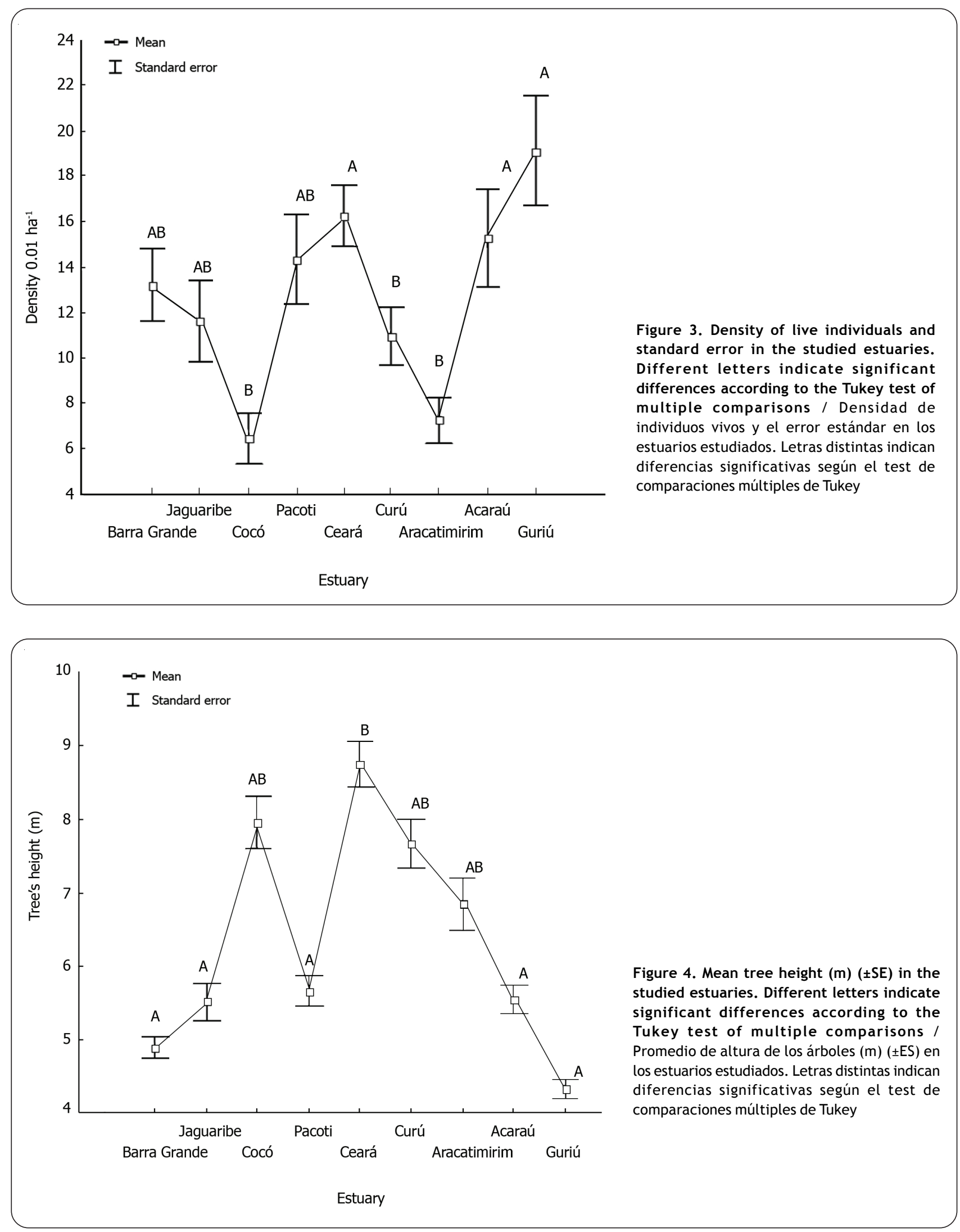
We also verified significant differences in DBH among the areas studied $\left(\mathrm{F}_{(8,126)}=8.378, P<0.001\right)$ (Fig. 5). The average values in Guriú River were significantly smaller than those found in the other sampled estuaries. The total sampled basal area was $17,178 \mathrm{~m}^{2}$, where the highest values were found in the estuaries of the Acaraú (2.68 $\left.\mathrm{m}^{2}\right)$, Ceará $\left(2.97 \mathrm{~m}^{2}\right)$ and Curú $\left(2.80 \mathrm{~m}^{2}\right)$ rivers, and the smallest in Guriú $\left(0.47 \mathrm{~m}^{2}\right)$ and Pacoti $\left(0.6005 \mathrm{~m}^{2}\right)$ (Table 2). As DBH values are used to measure basal area, these variables presented a similar pattern. The mangroves in Guriú presented similar and significantly smaller values than the other studied areas $\left(\mathrm{F}_{(8,126)}=4.275, P<0.001\right)$. DBH and basal area also show a tendency to diminish towards the west coast of the state, from Aracatimirim to Guriú.

The contribution of dead trunks within the sampled communities was low, registering only 33 individuals. The greatest abundance of them was found in Acaraú, where we registered 11 dead trees, whereas no dead individual was found in the estuaries of Guriú and Pacoti rivers. As occurred with living specimens, the highest average size was found in Ceará river estuary $(22.3 \pm 37.91 \mathrm{~m})$ while the highest DBH values were found in Jaguaribe ( $48.50 \pm$ $30.41 \mathrm{~cm})$. The highest average basal area was found in
Acaraú mangrove $\left(0.48 \pm 1.44 \mathrm{~m}^{2}\right)$, strongly influenced by the presence of a Rhizophora mangle tree with $248 \mathrm{~cm}$ DBH in this area.

The cluster analysis showed that the structure of the communities in the estuaries studied is different, with a distinct separation into three groups: the first one, composed by the estuaries of Acaraú, Pacoti and Jaguaribe rivers; the second, by Cocó and Ceará rivers; the third one, by Aracatimirim and Guriú (Fig. 6). The estuaries of Barra Grande and Curú were not grouped. Similarity analysis indicated that the sampled mangroves are significantly different in relation to relative density of mangrove species (Global $\mathrm{R}=0.574, P=0.027$ ). According to SIMPER it was possible to recognize the main species and their contribution to the formation of groups. Group 1 with $73.30 \%$ of similarity presented Rhizophora mangle with $45.34 \%$ and Avicennia germinans with $24.30 \%$ contribution as the most representative. The second group, with $64.18 \%$ of similarity, pointed to species $A$. schaueriana with $56.22 \%$ and $R$. mangle with $21.71 \%$ as the most representative. The third group's similarity was $64.18 \%$ having $R$. mangle contributing $59.19 \%$ and $A$. schaueriana with $33.95 \%$ for this grouping.
Figure 5. Mean DBH $(\mathrm{cm})( \pm \mathrm{SE})$ of trees in the studied estuaries. Different letters indicate significant differences according to the Tukey test of multiple comparisons / Promedio DAP $(\mathrm{cm})( \pm \mathrm{ES})$ de árboles en los estuarios estudiados. Letras distintas indican diferencias significativas según el test de comparaciones múltiples de Tukey

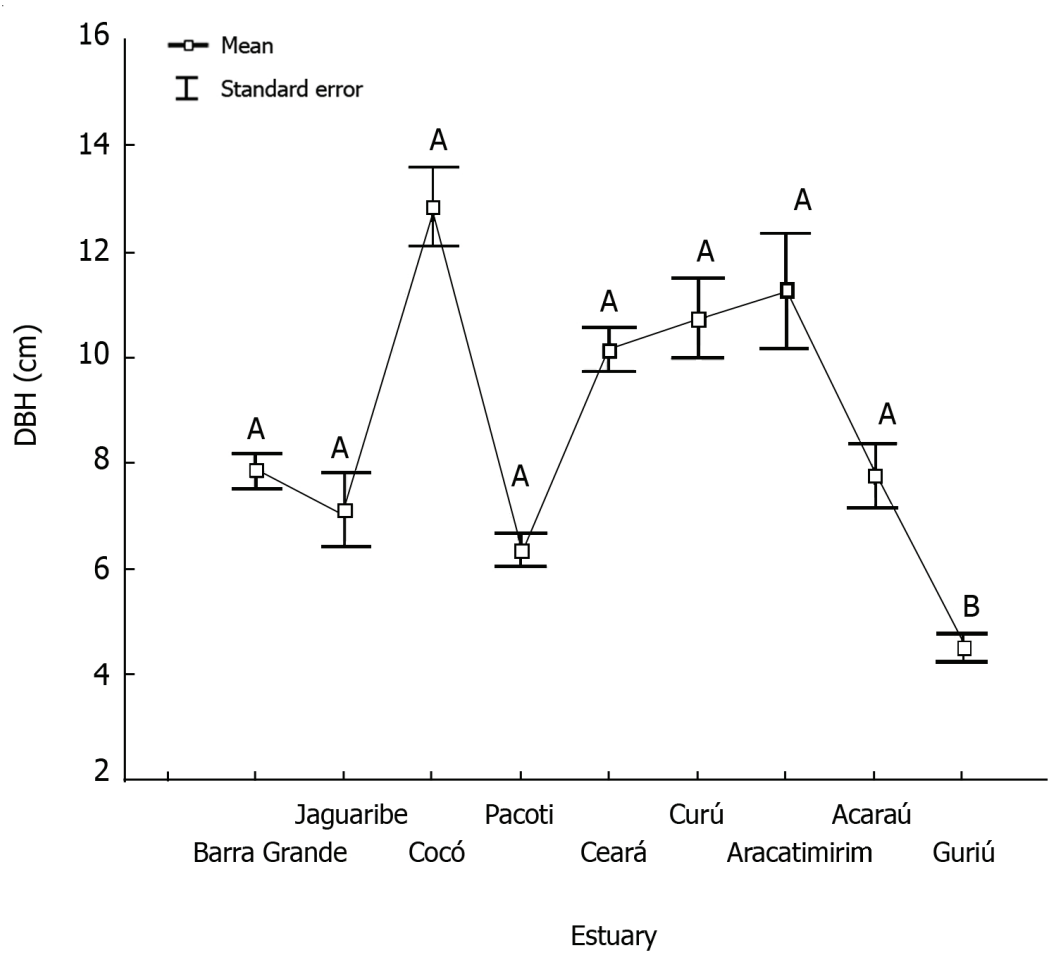

Vol. 47, №1, 2012 
The variation in sedimentary characteristics of the sampled areas corresponded to the first two axes of principal components analysis (PCA) (Fig. 7). The first PCA axis explained $91.6 \%$ of this variation and was positively correlated with fine sediment while showing a negative correlation with rock chips, sand and organic material. The second axis explained $8.4 \%$ and was positively correlated with fine sediment, rock chip and organic material and negatively with sand. The ordering of PCA indicated a variation in the distribution of sediments in the estuaries, referring to the samples collected in the Acaraú, Jaguaribe and Aracatimirim rivers that presented similar fine sediment values while the ones in Guriú and Barra Grande showed a similar content of rock chips, sand and organic material. In mangrove forests in the Ceará and Curú rivers we found similar fractions for all the variables studied, while the sediments in Pacoti and Cocó have similar values for rock chips, sand and fine sediment.

The correlation between structure, species composition, sediment and salinity parameters indicated a significantly high co-linearity between organic material content and tree height $(\mathrm{R}=0.71)$ and organic material content with total basal area of the individuals $(\mathrm{R}=0.81)$. The total basal area was negatively correlated to the percentage of sand $(R=-0.70)$. Also, the correlations between the dominance of Laguncularia racemosa and salinity $(\mathrm{R}=-0.68)$ and between rock chips and density of Avicennia schaueriana $(\mathrm{R}=0.74)$ were significant.

\section{Discussion}

The results for the specific composition of vegetation and structural parameters obtained for the nine estuaries studied showed differences in the mangrove forests, which can correspond to frequency variances and periodicity of subsidiary energies, such as tides, freshwater, entrance of nutrients (Schaeffer-Novelli \& Cintrón-Molero 1994), and the action of natural or anthropic tensors such as erosion, sedimentation and pollution (Soares 1999). For example, Rhizophora mangle finds very favorable conditions for good development in almost all the sampled areas, which is evidenced by its frequency and dominance. However, in some regions, Avicennia germinans or A. schaueriana were more frequent and dominant than $R$. mangle. The genus Avicennia is more tolerant to environmental stress and thus can be abundantly found in areas with humaninduced disturbances (Cintrón-Molero \& SchaefferNovelli 1992). In this study, $R$. mangle is suppressed by Avicennia spp in 2 areas of the metropolitan area of the state's capital, (estuaries of Cocó and Ceará rivers) and in an area with highlighted carciniculture activity (Jaguaribe River). In other words, places which are subjected to strong environmental disturbance.

The level of development or complexity that a mangrove can reach depends on external factors that fall into the system and regulate it. Data presented here show that mangroves in the state of Ceará have reduced development, regarding height, $\mathrm{DBH}$, and average basal area values, in comparison to other regions of the country and the world. For example, in Brazil, estuarial areas in the Rio de Janeiro state can reach up to an average of $9.9 \mathrm{~m}$ high and $13.4 \mathrm{~cm}$ of DBH (Bernini \& Rezende 2004) while in Espírito Santo state they can reach $12 \mathrm{~m}$ and $29.6 \mathrm{~cm}$, respectively (Silva et al. 2005). Pool et al. (1977) registered an average height of $17.7 \mathrm{~m}$ and average base area of 41.3 $\mathrm{m}^{2}$ for the forests of Florida, Puerto Rico and Mexico. While in Ceará state, in this study, we found $6.3 \mathrm{~m}$ height and $8.49 \mathrm{~cm}$ of DBH. Climatic characteristics contribute in determining its condition. The coastal zone of Ceará state is included in segment IV of Brazilian Coast Division proposed by Schaeffer-Novelli et al. (1990); in this area, the rainfall is reduced, which leads to accumulating salt. These factors may have contributed to the formation of smaller forests. Pool et al. (1977) also noticed a direct relation between structural development and the index of rain for the forests. In this study, they observed that in regions with humid weather in the Caribbean, the development of mangrove forests is significantly higher than in regions with dry weather.

The values for density also varied among the studied areas, the highest densities were observed in Acaraú, Ceará and Guriú mangroves while the lowest density was found in Aracatimirim, Cocó and Curú furthermore Barra Grande, Jaguaribe and Pacoti estuaries showed with intermediate values. We must take into consideration the fact that the density of forests is a function between age and maturing, due to the competition within the canopy for space (Schaeffer-Novelli \& Cintrón 1986). Thus, during a forests development, they go through a period in which land is occupied by a large density of trees, as such in the case of Acaraú, Ceará and Guriú mangroves, with reduced diameter, to a phase of higher maturing, when volume is made up by a few trees of large tonnage and volume as in Aracatimirim, Cocó and Curú mangrove forests, while Barra Grande, Jaguaribe and Pacoti would be in an intermediate stage of this process. Density, thus, is reduced through the forests' maturing. Although data in this study indicate a natural density reduction pattern, it only shows a clear gradient for DBH in the Guriú River estuary. 

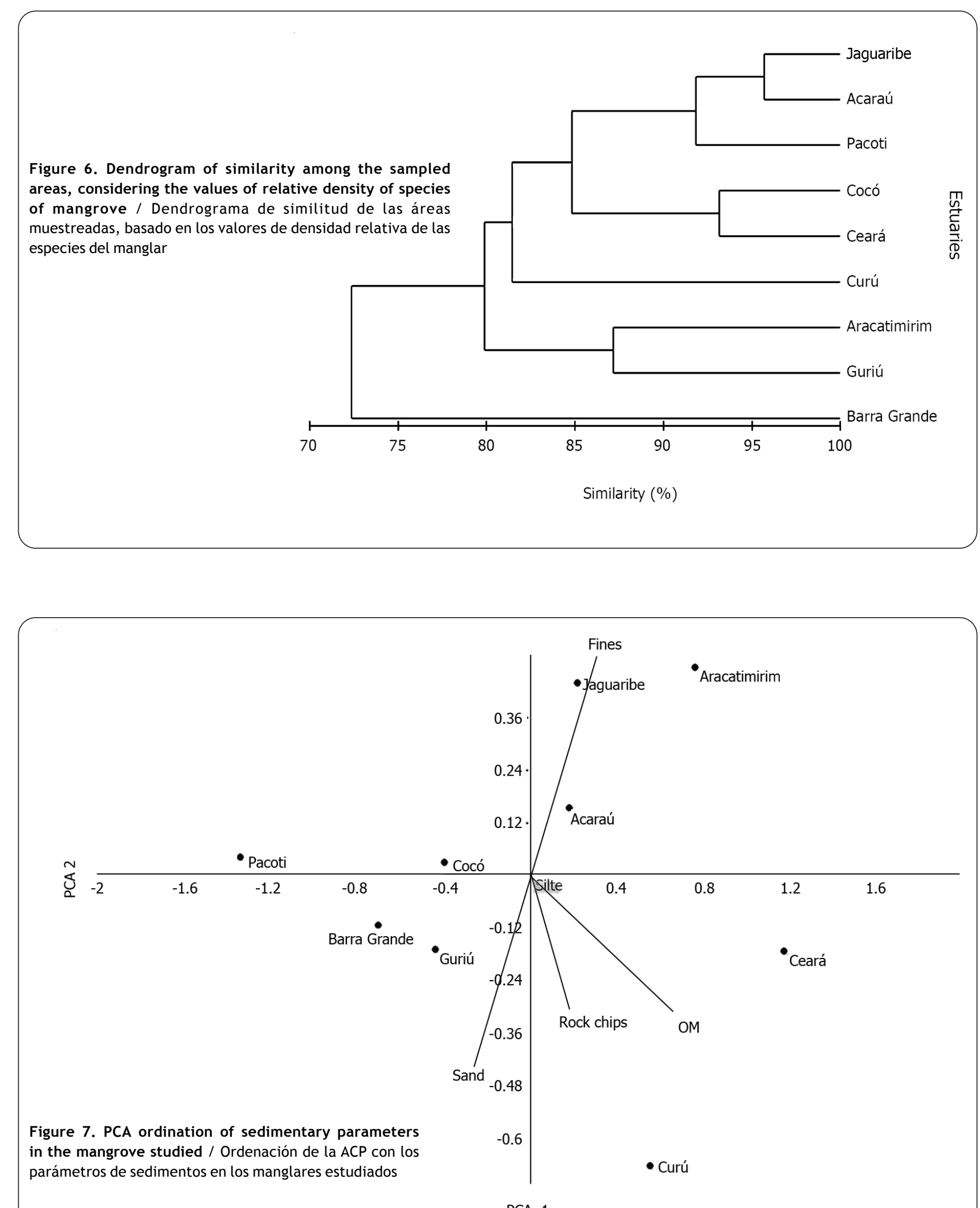

PCA 1 
In relation to the forests' level of development, considering height and basal area data, the areas studied are similar, except for the estuary of Guriú River that presents the lowest values, significantly different from the other estuaries. Trunk/individual relation of mangrove forests in this study was nearly one. In general, well developed forests, growing under proper conditions, have a relation value close to the one presented (SchaefferNovelli \& Cintrón 1986). For dead trunks, the evaluated parameters were highly varied, indicating the impact of local factors as rates of tree growth, intensity and frequency of tensors in mortality. The absence of dead trees in Guriú River may indicate once more that these forests are in an initial stage of development.

Cluster analysis indicates that the mangrove forests sampled, although being submitted to similar regional conditions, present local characteristics. For example, estuaries of Cocó and Ceará, due to geographic proximity of the metropolitan region, are subject to the impacts of the same tensors, such as erosion, fast sedimentation, hydrodynamics and freshwater intake that determine the levels of degradation and regeneration of plants, factors that influence the forests' structure (Soares 1999). Pacoti's mangrove, although in the same area, presents a different community composition; no grouping with the others is observable. Acaraú and Jaguaribe are similar because they present similar values for all structure parameters evaluated. Aracatimirim and Guriú are also geographically close. Furthermore, estuaries in Barra Grande and Curú present the highest density values, dominance and frequency of Rhizophora mangle, no grouping with the others observable. Due to the great dominance of $R$. mangle in most of the areas, density and frequency of the other species are determining factors regarding dissimilarity among the groups.

The percentage of inorganic fractions of sediment were also variable according to the studied sites, which can correspond to variations of tide cycles in each area, taking into account the differences in the specific composition of communities as suggested by Tolhurst \& Chapman (2005). Salinity, for example, in this study was a decisive factor for Laguncularia racemosa density, presenting a negative correlation with this factor. It is also important to highlight that the content of organic material was positively correlated to the values of tree height and total basal area, meaning that, areas richer in nutrients lead to higher levels of forest development, superposing the other factors that act upon the region. However, the weak correlation found by comparative analysis between the biotic and abiotic factors suggests that other variables are responsible for the structure of the communities sampled, such as the degree of human disturbance which is difficult to quantify.

In summary, the variability in the specific composition, in the structural development and in sedimentary characteristics found in this study showed the great variability of mangroves in the state of Ceará. Thus, they have the potential to accommodate in the face of strong environmental differences seen between geographically close sites, such as hydrodynamics, freshwater intake, nutrient availability and environmental impacts. These differences must be taken into consideration when proposing plans for management, as each mangrove demands different strategies for its maintenance (Schaeffer-Novelli \& Cintrón-Molero 1994). For example, to keep the ecological balance of estuarial areas, such as the ones studied here, there should be zones for the protection of preserved mangrove on riverbanks, in front of the sea. The group formed in the cluster analysis of the estuaries of Ceará and Cocó, for instance, should be conserved exclusively for sustainable use as they are close to an urban center, as well as for coastal protection, tourism, education and recreational uses especially by the locals who must be involved in the eventual efforts of reforestation and maintenance of the ecosystem. In mangrove areas exposed to significant environment threats (e.g., carciniculture) or fishing sites, such as the mangroves in Jaguaribe, Acaraú and Pacoti, another group formed in our analyses, a minimal protection zone of forest should be left untouched for its preservation.

Generally, there is a great lack of updated reference information to support the management of mangrove ecosystems. First, studies, like the one presented here, must be done to evaluate all mangrove areas. Then we will be able to implement a simple indicator, with the wood structure to monitor environmental changes. We should also strengthen and develop institutions and systems using existing information and establish databases and patterned procedures to collect, group, retain and spread mangrove-related information. These reference banks shall be integrated in an international database and frequently updated, thus becoming a tool for decisionmaking in relation to the management of mangrove forests around the world. 


\section{ACKNOWLEDGEMENTS}

We give thanks to the Centro de Aperfeiçoamento Pesquisa de Ensino Superior (CAPES) for granting a Scholarship for the first author. To J. N. Maia, P. S. Ribeiro, M. Filho, M. Rodrigues, C. Moreira and L. Barbosa for aid during the field trip.

\section{LITERATURE CITED}

Alongi DM. 2002. Present state and future of the world's mangrove forests. Environmental Conservation 29: 331349.

Atheull AN, N Din, SN Longonje, N Koedam, F DahdouhGuebas. 2009. Commercial activities and subsistence utilization of mangrove forests around the Wouri estuary and the Douala-Edea reserve (Cameroon). Journal of Ethnobiology and Ethnomedicine 5: 35: 1-14.

Bernini E \& CE Rezende. 2004. Estrutura da vegetação em florestas de mangue do estuário do rio Paraíba do Sul, Estado do Rio de Janeiro, Brasil. Acta Botanica Brasilica 18: 491502.

Cavalcanti VE, MLG Soares, GCD Estradat \& FO Chavest. 2009. Evaluating mangrove conservation through the analysis of forest. Journal of Coastal Research 56: 390394.

Cintrón-Molero G \& Y Schaeffer-Novelli. 1992. Ecology and management New World mangroves. In: Seeliger U (ed). Coastal plant communities of Latin America, pp. 233-258. Academic Press, San Diego.

Clarke KR \& RN Gorley. 2006. PRIMER v6: user manual/ Tutorial, 190 pp. Primer-E, Plymouth.

Cunha-Lignon M, C Coelho Jr, R Almeida, R Menghini, F Correa, Y Schaeffer-Novelli, G Cintrón-Molero \& F Dahdouh-Guebas. 2009. Mangrove forests and sedimentary processes on the South Coast of São Paulo State (Brazil). Journal of Coastal Research, Special Issue 56: 405-409.

Ellison AM \& EJ Farnsworth. 1996. Anthropogenic disturbance of Caribbean Mangrove ecosystems: past impacts, present trends and future predictions. Biotropica 28: 549-565.

Ellison AM \& EJ Farnsworth. 2001. Mangrove communities. In: Berthness MD, S Gaines \& ME Hey (eds). Marine community ecology, pp. 323-442. Sinauer Press, Surderland.

FAO. 2007. The world's mangrove: 1980- 2005 - A thematic study prepared in the framework of the Global Forest Resources Assessment, 89 pp. Food and Agriculture Organization of the United Nations, Rome.

Fleming MF, G Lin \& LSL Sternberg. 1990. Influence of mangrove detritus in an estuarine ecosystem. Bulletin of Marine Science 47: 663-669.
Fondo EN \& EE Martens. 1998. Effects of mangrove deforestation on macrofaunal densities, Gazi bay, Kenya. Mangroves and Salt Marshes 2: 75-83.

Gilman EL, J Ellison, NC Duke \& C Field. 2008. Threats to mangroves from climate change and adaptation options: a review. Aquatic Botany 89: 237-250.

Jablonski S \& M Filet. 2008. Coastal management in Brazil -a political riddle. Ocean \& costal Management 51: 536543.

Loring DH \& RTT Rantala. 1992. Manual for the geochemical analyses of marine sediments and suspended particulate matter. Earth-Science Reviews 32: 235-283.

Lugo AE \& SC Snedaker. 1974. The ecology of mangroves. Annual Review of Ecology and Systematics 5: 39-64.

Menghini RP, C Coelho Jr, AS Rovai, M Cunha-Lignon, Y Schaeffer-Novelli \& G Cintrón. 2011. Massive mortality of Mangrove forests in southeast Brazil (Barnabé Island, Baixada Santista, State of São Paulo) as a result of harboring activities. Journal of Coastal Research, Special Issue 64: 1793-1797.

Nascimento IA, SA Pereira \& ELV Dória. 2007. Identificação e prevenção de impactos em manguezais: relação com atividades de carcinicultura. Diálogos \& Ciência 11: 1-11.

Peria LCS, PPCP Fernandes, GV Menezes, M Grasso \& MMP Tognella. 1990. Estudos estruturais comparativos entre bosques de manguezais impactados (Canal da Bertioga) e não impactados (Ilha do Cardoso), estado de São Paulo. Segundo Simpósio de Ecossistemas da Costa Brasileira. Estrutura, Função e Manejo, ACIESP 2: 183-193.

Pool DJ, SC Snedaker \& AE Lugo. 1977. Structure of mangrove forests in Florida, Puerto Rico, México and Costa Rica. Biotropica 9: 195-212.

Robertson AI \& PA Daniel. 1989. Decomposition and the annual flux of detritus from fallen timber in Tropical Mangrove Forests. Limnology and Oceanography 34: 640646.

Schaeffer-Novelli Y. 1995. Manguezal ecossistema entre a terra e o mar, 64 pp. Caribbean Ecological Research, São Paulo.

Schaeffer-Novelli Y \& G Cintrón. 1986. Guia para estudo de áreas de manguezal: estrutura, função e flora, 25 pp. Caribbean Ecological Research, São Paulo.

Schaeffer-Novelli Y \& G Cintrón-Molero. 1994. Manguezais brasileiros: uma síntese sobre aspectos históricos (séculos XVI a XIX), zonação, estrutura e impactos ambientais. In: Anais do Simpósio de Ecossistemas da Costa Brasileira. Subsídios a um gerenciamento ambiental. São Paulo, ACIESP 1: 333-341.

Schaeffer-Novelli Y, G Cintrón-Molero, RR Adaime \& TM Camargo. 1990. Variability of mangrove ecosystems along the Brazilian coast. Estuaries 13: 204-218. 
Schaeffer-Novelli Y, G Cintrón-Molero, MLG Soares \& T De Rosa. 2000. Brazilian mangroves. Aquatic Ecosystem Health and Management 3: 561-570.

Spalding M, M Kainuma \& L Collins. 2010. World atlas of mangroves, 319 pp. Earthscan, Washington.

SEMACE. 2006. Manguezais do nordeste do Brasil - Avaliação das áreas de manguezais dos Estados do Piauí, Ceará, Rio Grande do Norte, Paraíba e Pernambuco, 125 pp. SEMACE, Fortaleza.

Sheridan P \& C Hays. 2003. Are mangroves nursery habitat for transient fishes and decapods? Wetlands 23: 449-458.

Silva MAB, E Bernini \& TMS Carmo. 2005. Características estruturais de bosques de mangue do estuário do rio São Mateus, ES, Brasil. Acta Botanica Brasilica 19: 465-471.

Soares MLG. 1999. Estrutura vegetal e grau de perturbação dos manguezais da lagoa da Tijuca, Rio de Janeiro, RJ, Brasil. Revista Brasileira de Biologia 59: 5003-5015.
Soares MLG. 2009. A conceptual model for the responses of mangrove forests to sea level rise. Journal of Coastal Research 56: 267-271.

Soares MLG, FO Chaves, FM Corrêa \& CMG Silva Jr. 2003. Diversidade estrutural de bosques de mangue e sua relação com distúrbios de origem antrópica: O caso da Baía de Guanabara (Rio de Janeiro). Anuário do Instituto de Geociências 26: 101-116.

Souza MMA \& EVSB Sampaio. 2001. Variação temporal da estrutura de bosques de mangue de Suape-PE após a construção do Porto. Acta Botanica Brasilica 15: 1-12.

Tolhurst TJ \& MG Chapman. 2005. Spatial and temporal variation in the sediment properties of an intertidal mangrove forest: implications for sampling. Journal of Experimental Marine Biology and Ecology 317: 213-222.

Vannucci M. 2001. What is so special about mangroves? Brazilian Journal of Biology 61: 599- 603.

Received 6 October 2011 and accepted 7 March 2012 